Research article

\title{
Increased Activity Tolerance based on Hemodynamic Status in Patients Coronary Heart Disease After Physical Rehabilitation of Phase I (Inpatient)
}

\author{
Wiwiek Retti Andriani', Endang Purwaningsih ${ }^{2}$ \\ 1,2 Departemen Keperawatan, Prodi D3 Keperawatan Ponorogo, Politeknik Kesehatan Kemenkes Malang
}

\begin{tabular}{|c|c|}
\hline Article Info & Abstract \\
\hline $\begin{array}{l}\text { Article History: } \\
\text { Accepted } 8 \text { Desember } 2019 \\
\text { Key words: } \\
\text { Rehabilitative phase I } \\
\text { Inpatient, Tolerance activity, } \\
\text { Hemodynamic Status, Acute } \\
\text { Coronary Syndrome }\end{array}$ & $\begin{array}{l}\text { Coronary Heart Disease (CHD) is caused by atheroma/plaque attached to the } \\
\text { endothelial lining of the coronary arteries which causes blockages in oxygen } \\
\text { and nutrient distribution to the tissues. This condition causes CHD patients } \\
\text { to experience deficits in functional capacities, such as self-care ability, } \\
\text { incapacity for performing the activity of daily living and also social activities. } \\
\text { This study aims to analyze activity tolerance based on hemodynamic status } \\
\text { (respiration, blood pressure, pulse frequency, oxygen saturation) in CHD } \\
\text { patients after phase } 1 \text { physical rehabilitation (inpatient). The research } \\
\text { method is quasy experiment one group pre-post-test research method. The } \\
\text { results of data analysis using the Friedman test found that there was a } \\
\text { significant effect on respiration on days } 2,3 \text {, systolic blood pressure on days } \\
1 \text { and } 3 \text {, no significant effect on diastolic blood pressure, significant changes } \\
\text { in oxygen saturation on days } 1,2 \text {, and } 3 \text {, changes in pulse frequency on days } \\
1 \text { and } 3 \text {. }\end{array}$ \\
\hline
\end{tabular}

\section{PENDAHULUAN}

Penyakit Jantung Koroner (PJK) atau Sindrom Koroner Akut (SKA) merupakan penyakit iskemik miokard berkepanjangan sehingga menyebabkan kematian otot jantung (Mozaffarian et al., 2016). PJK terjadi penyempitan/sumbatan arteri koroner yang mengakibatkan tidak terpenuhinya oksigen ke otot jantung (Bachrudin \& Najib, 2016). Berkurangnya aliran oksigen ke miokard berdampak pada aktivitas sehari-hari (activity daily living) ringan-berat, kegagalan ventrikel kiri dan akhirnya penurunan cardiac output (hemodinamik tidak stabil) (Overbaugh, 2009).
World Health Organization (WHO) pada tahun 2012 menyebutkan lebih dari 17.5 juta orang meninggal akibat penyakit jantung atau 31\% dari 56.5 juta kematian di seluruh dunia (Biro Komunikasi dan Pelayanan Masyarakat, 2017). Insiden PJK di Indonesia sejumlah 1,5\% atau 15 dari 1.000 penduduk Indonesia (Riskesdas, 2018). Prevalensi PJK di Jawa Timur pada tahun 2013 berdasarkan diagnosis dokter sebesar $0,5 \%$ atau sekitar 144.279 penderita (Kemenkes, 2014). Pasien PJK yang menjalani rawat inap di ICCU RSUD Dr. Harjono Ponorogo tahun 2017 sejumlah 256 pasien (rata-rata 21 pasien/bulan) (RSUD. Harjono Ponorogo, 2017). 
Rehabilitasi jantung mampu menurunkan angka mortalitas penyakit kardiovaskuler (RR: 0.82; 95\%, CI: 0.70-0.96). Pelayanan rehabilitasi jantung di negara maju tercatat $40 \%$ di seluruh dunia, sedangkan pelayanan negara rendah - menengah hanya $22 \%$. Ryandini dalam penelitiannya tentang penerapan teori self care untuk mengatasi intoleransi aktivitas pada pasien gangguan kardiovaskuler menunjukkan 31 pasien gangguan kardiovaskuler 55\%-nya adalah PJK, dan 40\% dari kasus tersebut mengalami intoleransi aktivitas dalam pemenuhan kebutuhan sehari-hari (Ryandini, Nurachmah, Herawati, Adam, \& Sekarsari, 2017). Beberapa penelitian merekomendasikan program rehabilitasi fisik pada pasien PJK untuk mengatasi masalah intoleran aktivitas (Delima, Sriati, \& Nur'aeni, 2018).

Pada PJK arteri koroner mengalami sumbatan karena thrombus/plak dari timbunan lipid pada pembuluh darah jantung dan mengalami iskemik hingga suplai oksigen menurun (Asikin, Nuralamsyah, \& Susaldi, 2016). Gangguan suplai oksigen akan meningkatkan produksi asam laktat yang memunculkan hambatan kontraksi otot jantung dan chest pain. Berkurangnya pasokan oksigen membuat terjadinya metabolism anaerob (Hernawati, 2006). Hasil metabolism anerob adalah energy sejumlah 2 ATP dari kebutuhan normal 36 ATP per 1 molekul glukosa. Akibatnya pasien PJK mengalami kelemahan dan kelelahan (intoleransi aktivitas) (Muttaqin, 2012). Kondisi tersebut berdampak pada penurunan kapasitas fungsional (Suharsono, 2013). Lapisan otot jantung yang menebal mengganggu kontraksi ventrikel (peningkatan denyut jantung) yang menyebabkan cedera endotel. Cedera tersebut berdampak pada peningkatan Low Density Lipoprotein (LDL) sehingga lebih mudah invasi ke lapisan pembuluh darah tunika intima. LDL yang masuk dalam tunika intima berpotensi terjadi aterosklerosis dan meningkatkan tekanan hemodinamik (Neumar et al., 2010).
Kebutuhan oksigen pada otot miokard dapat dilihat dari indikator denyut jantung (heart rate), tekanan dinding ventrikel dan otot kontraksi jantung (keadaan inotropik). Atherosklerosis pada iskemia membuat konsumsi oksigen meningkat serta perfusi miokard menurun yang menstimulus produksi katekolamin, sehingga menyebabkan peningkatan denyut jantung dan berdampak meluasnya nekrosis miokard yang memicu terjadi MACE (Major Adverse Cardiac Events) pada pasien PJK (Lilly, 2011).

Manajemen perawatan diri mempunyai tingkat keberhasilan tinggi pada tatalaksana pasien PJK. Kegiatan itu diantaranya adalah latihan fisik (PERKI, 2015). Program rehabilitasi fisik jantung merupakan salah satu terapi nonfarmakologis dan indikasi utama pada PJK (Zanto, Hennigan, Östberg, Clapp, \& Gazzaley, 2011). Program ini akan tercapai saat ada 3 kesiapan komponen: (1) penerapan rehabilitasi fisik dini, (2) pendidikan kesehatan pada pasien dan keluarga, (3) Kesiapan tim pelaksana rehabilitasi (Rokhaeni, Purnamasari, \& Rahayoe, 2001). Program rehabilitasi fisik asien jantung terdiri dari 3 fase: (1) Fase I (inpatient), (2) Fase II (outpatient), (3) Fase III (maintenance) (Sudibjo, Arovah, \& A, 2013). Rahabilitasi fisik jantung berfungsi memulihkan gangguan seperti penurunan fungsi kapasitas paru, penurunan kekuatan otot, hipotensi ortostatik, dan ansietas yang disebabkan bedrest lama (Badriyah, Kadarsih, \& Istanti, 2010). Penerapan program rehabilitasi fisik jantung terbukti aman bagi pasien, dan belum ditemukan adanya reinfark atau mortalitas dan efektif melatih mobilitas dan kerja jantung (Lavie \& Milani, 2011).

Penerapan program rehabilitasi fisik jantung sudah diterapkan di beberapa rumah sakit provinsi, namun selama ini belum pernah dilaksanakan di RSUD Dr, Harjono Ponorogo. Pelayanan di unit intensive care tidak ada tim rehabilitasi/fisiotepist yang selalu ada di 
ruangan. Oleh karena itu peran perawat dalam program rehabilitasi fisik inpatient sangat diperlukan. Progam ini dapat dilakukan dengan persetujuan dokter penanggungjawab pada pasien. Penelitian ini bertujuan untuk menganalisis pengaruh program rehabilitasi fisik fase I (inpatient) terhadap peningkatan toleransi aktivitas berdasarkan status hemodinamik pasien PJK.

\section{METODE}

Penelitian ini menggunakan desain quasy experiment pre-post test without control group. Tehnik sampling consecutive sampling dengan besar sampel 30 responden yang dihitung dengan rumus Sastroasmoro \& Ismael (2008). Populasi dalam penelitian adalah semua pasien PJK dan di dapatkan 30 responden yang memenuhi kriteria inklusi pasien PJK kategori NSTEMI paska serangan yang telah dinyatakan stabil oleh dokter penanggung jawab, pasien dalam kondisi sadar, dan bersedia dilibatkan menjadi responden. Pasien dengan kriteria eklusi: tekanan darah sistolik $>150 \mathrm{mmHg}$, demam $>375$ oC, pasien PJK dengan masalah musculoskeletal (kelemahan/ kelumpuhan/kecacatan), Takikardi (nadi > $130 \mathrm{x} / \mathrm{mnt}$ ), Congestive Heart Failure (CHF) fungsional kelas III-IV. Sedangkan kriteria drop out : pasien NSTEMI yang mengalami kelemahan saat latihan aktivitas fase I, pasien yang tiba-tiba muncul keluhan insufisiensi perifer saat latihan aktivitas fase I, adanya perubahan EKG saat rehabilitasi berlangsung (SVT, AV Block, VES, VT), saat dilakukan aktivitas latihan terjadi kenaikan TD Sistolik > $20 \mathrm{mmHg}$.

Penelitian dilakukan setelah mendapatkan ethical clearance dari Komisi Etik Penelitian Kesehatan (KEPK) RSUD Dr, Harjono Ponorogo. Peneliti dibantu assisten/pembantu peneliti (perawat ruang ICCU) memilih responden yang telah ditetapkan kemudian diberikan informed consent dan penjelasan prosedur penelitian.
Instrumen yang digunakan adalah lembar observasi toleransi aktivitas dari indikator Nursing Outcomes Criteria (NOC) yang dimodifikasi peneliti meliputi: respirasi, tekanan darah sistolik - diastolik, saturasi oksigen, frekuensi nadi. Monitor hemodinamik digunakan mengukur tekanan darah, gelombang denyut jantung, frekuensi nafas, dan saturasi oksigen ang terhubung dengan elektroda yang menempel pada dada pasien.

Intervensi program rehabilitasi fisik dilakukan selama 3 hari berturut-turut, dengan 2 sesi latihan/hari (pagi dan sore). Tiap sesi latihan dengan durasi 10-20 menit. Penilaian toleransi aktivitas dilakukan pre-test (sebelum intervensi), dan post-test setiap hari setelah intervensi sore hari.

Data dianalisis secara univariate da bivariate menggunakan SPSS versi 15. Analisis univariate disajikan secara numeric dan kategorik. Data kategorikal berasal dari demografi seperti: usia, jenis kelamin, pendidikan, riwayat penyakit sebelumnya, riwayat penyakit keluarga disajikan secara distribusi frekuensi. Data di uji normalitas dengan Shapiro-wilk. Sedangkan uji bivariate menggunakan uji Friedman.

\section{HASIL}

Penelitian ini dilakukan pada 30 orang responden PJK NSTEMI sesuai dengan kriteria inklusi yang ditetapkan. Hasil penelitian pada tabel 1 menunjukkan bahwa jenis kelamin responden $56.7 \%$ perempuan, usia responden $56.7 \%$ lansia akhir, tingkat pendidikan responden $80.0 \%$ pendidikan dasar, riwayat penyakit sebelumnya $63.3 \%$ pernah mengalami sakit stroke/asma/ tulang/dll, 83.3\% menyatakan tidak pernah melakukan olahraga. Sedangkan $46.6 \%$ riwayat penyakit keluarga adalah asma/stroke/paru-paru. 
Tabel 1

Karakteristik responden, $\mathrm{n}=30$ responden

\begin{tabular}{|c|c|c|}
\hline Karakteristik Responden & $\mathrm{f}$ & $\%$ \\
\hline \multicolumn{3}{|l|}{ Jenis Kelamin } \\
\hline Laki-laki & 13 & $43.3 \%$ \\
\hline Perempuan & 17 & $56.7 \%$ \\
\hline \multicolumn{3}{|l|}{ Usia } \\
\hline $46-55$ tahun & 17 & $56.7 \%$ \\
\hline $56-64$ tahun & 6 & $20.0 \%$ \\
\hline$>65$ tahun & 7 & $23.3 \%$ \\
\hline \multicolumn{3}{|l|}{ Pendidikan } \\
\hline Tidak Sekolah & 4 & $13.3 \%$ \\
\hline $\begin{array}{l}\text { Pendidikan Dasar (SD, } \\
\text { SMP) }\end{array}$ & 24 & $80.0 \%$ \\
\hline $\begin{array}{l}\text { Pendidikan Menengah } \\
\text { (SMA) }\end{array}$ & 2 & $6.7 \%$ \\
\hline $\begin{array}{l}\text { Perguruan Tinggi } \\
\text { (Diploma/Sarjana) }\end{array}$ & 0 & $0.0 \%$ \\
\hline \multicolumn{3}{|l|}{ Riwayat Penyakit } \\
\hline \multicolumn{3}{|l|}{ Sebelumnya } \\
\hline Hipertensi & 6 & $20.0 \%$ \\
\hline Diabetes Mellitus & 5 & $16.7 \%$ \\
\hline Stroke & 0 & $0.0 \%$ \\
\hline $\begin{array}{l}\text { Lainnya (Asma, } \\
\text { Osteoporosis, dll) }\end{array}$ & 19 & $63.3 \%$ \\
\hline \multicolumn{3}{|l|}{ Kebiasaan Olahraga } \\
\hline Rutin & 0 & $0.0 \%$ \\
\hline Tidak Rutin & 5 & $16.7 \%$ \\
\hline Tidak Pernah & 25 & $83.3 \%$ \\
\hline \multicolumn{3}{|l|}{ Riwayat Penyakit } \\
\hline Hipertensi & 9 & $30.0 \%$ \\
\hline Diabetes Mellitus & 5 & $16.7 \%$ \\
\hline $\mathrm{PJK}$ & 2 & $6.7 \%$ \\
\hline $\begin{array}{l}\text { Penyakit lainnya (Asma, } \\
\text { Stroke, dll) }\end{array}$ & 14 & $46.6 \%$ \\
\hline
\end{tabular}

Hasil penelitian pada gambar 1 adalah variabel dependen penelitian yaitu toleransi aktivitas pre-post test selama 3 hari. Didapatkan respirasi responden sebelum intervensi mean $25 \mathrm{x} /$ menit, setelah hari ketiga mean menjadi 16 $\mathrm{x} /$ menit. Tekanan darah sistolik sebelum intervensi mean $130 \mathrm{mmHg}$, setelah 3 hari mean 120 mmHg. Tekanan darah diastolik tidak banyak perubahan pre-post test. Saturasi oksigen saat pre-test, mean 90\% menjadi $100 \%$ setelah hari ketiga. Sedangkan heart rate (Frekuensi nadi) sebelum intervensi mean $110 \mathrm{x} /$ menit dan setelah hari ketiga mean $80 \mathrm{x} /$ menit.

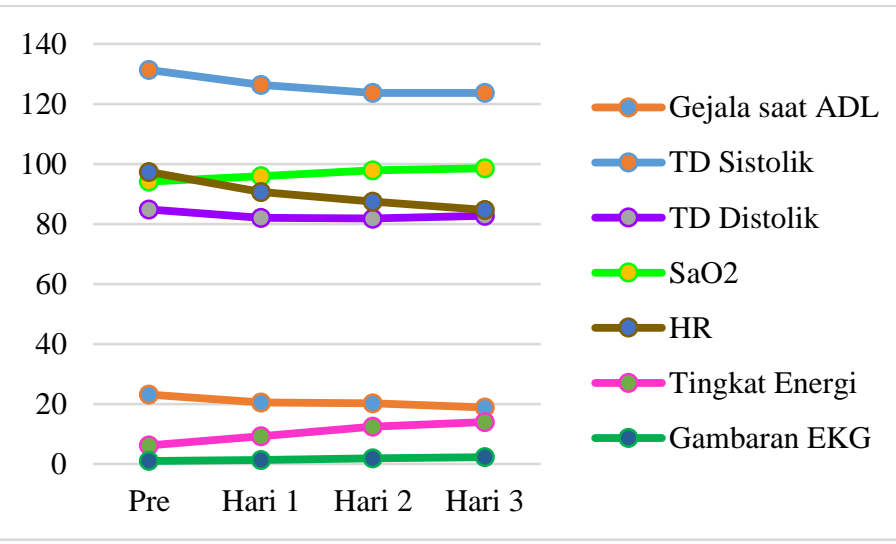

Gambar 1

Perubahan toleransi aktivitas sebelum dan setelah diberikan intervensi rehabilitasi fisik fase I

(inpatient) pada hari kesatu, kedua, dan ketiga

Hasil analisis bivariate pada tabel 2 tentang rata-rata toleransi aktivitas berdasarkan status hemodinamik didapatkan RR pada responden sebelum intervensi adalah 23.13 $\mathrm{x} /$ menit sedangkan setelah intervensi 3 hari menjadi $18.83 \mathrm{x} /$ menit. Tekanan darah sistolik sebelum intervensi $131.33 \mathrm{mmHg}$ menjadi $123.67 \mathrm{mmHg}$. Tekanan darah diastolic sebelum intervensi $84.83 \mathrm{mmHg}$ setelah 3 hari menjadi $82.67 \mathrm{mmHg}$. Perubahan saturasi oksigen sebelum intervensi $94.13 \%$ menjadi $98.57 \%$ setelah intervensi. Frekuensi nadi sebelum intervensi $97.33 \mathrm{x} /$ menit setelah intervensi selama 3 hari $84.67 \mathrm{x} /$ menit.

Tabel 2

Rata-rata pengukuran toleransi aktivitas responden setelah intervensi rehabilitasi fisik fase I (inpatient) pada hari kesatu, kedua, dan ketiga di Ruang ICCU

RSUD Dr. Harjono Ponorogo, n=30 responden

\begin{tabular}{lcccc}
\hline \multirow{2}{*}{ Variabel } & \multirow{2}{*}{ Pre } & Hari ke- & Hari ke- & Hari ke- \\
& & 1 & 2 & 3 \\
\cline { 2 - 5 } & Mean \pm & Mean \pm & Mean \pm & Mean \pm \\
& SD & SD & SD & SD \\
\hline \multirow{2}{*}{ Respirasi } & $23.13 \pm$ & $20.53 \pm$ & $20.27 \pm$ & $18.83 \pm$ \\
TD & 2.129 & 1.279 & 2.258 & 2.506 \\
Sistolik & $131.33 \pm$ & $126.33 \pm$ & $123.67 \pm$ & $123.67 \pm$ \\
TD & 8.996 & 8.899 & 7.184 & 7.649 \\
Diastolik & $84.83 \pm$ & $82.00 \pm$ & $81.83 \pm$ & $82.67 \pm$ \\
SaO2 & 5.167 & 5.960 & 6.170 & 82.67 \\
& $94.13 \pm$ & $95.97 \pm$ & $97.83 \pm$ & $98.57 \pm$ \\
Nadi & 1.756 & 1.217 & 1.416 & 2.079 \\
& $97.33 \pm$ & $90.67 \pm$ & $87.50 \pm$ & $84.67 \pm$ \\
& 12.299 & 9.444 & 11.945 & 10.417 \\
\hline
\end{tabular}

Hasil analisis bivariate dengan uji Friedman tentang pengaruh program rehabilitasi fisik fase I (inpatient) dengan toleransi aktivitas 
pada tabel 3 didapatkan nilai $p$ value $<0.05$. Hasil tersebut membuktikan bahwa terdapat perbedaan nilai pengukuran variabel toleransi aktivitas (respirasi, tekanan darah, saturasi oksigen, frekuensi nadi) pada responden sebelum dan setelah diberikan intervensi. Berdasarkan hasil tersebut dapat disimpulkan bahwa $\mathrm{Ha}$ diterima, yang artinya ada pengaruh rehabilitasi fisik fase I (inpatient) terhadap toleransi aktivitas pada pasien PJK NSTEMI di ruang ICCU RSUD Dr. Harjono Ponorogo. Kecuali pada variabel tekanan darah sistolik dan diastolik $p$ value $>0.05$.

Tabel 3

Pengaruh program rehabilitasi fisik fase I terhadap toleransi aktivitas responden setelah intervensi rehabilitasi fisik fase I (inpatient) pada hari kesatu, kedua, dan ketiga di Ruang ICCU RSUD Dr. Harjono Ponorogo, $n=30$ responden

\begin{tabular}{lcccc}
\hline & \multicolumn{4}{c}{ Waktu } \\
\cline { 2 - 5 } Variabel & $\begin{array}{c}\text { Pre }- \\
\text { Hari ke 3 }\end{array}$ & $\begin{array}{c}\text { Hari ke } \\
1-2\end{array}$ & $\begin{array}{c}\text { Hari ke } \\
1-3\end{array}$ & $\begin{array}{c}\text { Hari ke } \\
2-3\end{array}$ \\
\cline { 2 - 5 } & Pvalue & Pvalue & Pvalue & P value \\
\hline RR & $\mathbf{0 . 0 0 0}$ & 0.221 & $\mathbf{0 . 0 1 4}$ & $\mathbf{0 . 0 0 6}$ \\
TD & $\mathbf{0 . 0 0 9}$ & $\mathbf{0 . 0 3 3}$ & 0.180 & 0.763 \\
$\begin{array}{l}\text { Sistolik } \\
\text { TD }\end{array}$ & 0.074 & 0.819 & 1.000 & 0.617 \\
$\begin{array}{l}\text { Diastolik } \\
\text { SaO2 }\end{array}$ & $\mathbf{0 . 0 0 0}$ & $\mathbf{0 . 0 0 0}$ & $\mathbf{0 . 0 0 0}$ & 0.059 \\
$\begin{array}{l}\text { Heart } \\
\text { rate }\end{array}$ & $\mathbf{0 . 0 0 1}$ & 0.162 & $\mathbf{0 . 0 1 2}$ & 0.180 \\
\hline
\end{tabular}

\section{PEMBAHASAN}

Karakteristik responden berdasarkan jenis kelamin perempuan sedikit lebih banyak (56.7\%) dibandingkan responden laki-laki. Wanita yang telah menopause (berusia di atas 50 tahun), berpotensi besar mengalami penyakit jantung koroner. Hal ini dikarenakan penurunan kadar hormon estrogen yang berfungsi melindungi pembuluh darah dan peningkatan kolesterol LDL dalam tubuh sehingga meningkatkan resiko gangguan jantung. American Heart Association (AHA) melaporkan lebih dari $1 / 3$ penyakit kardiovaskular (jantung koroner) terjadi pada wanita dewasa (Greenland P, et al., 2010).
Usia responden (56.7\%) termasuk kategori usia lansia awal (46-55 tahun). Prevalensi jantung koroner meningkat lima kali pada usia 40-60 tahun, dikarenakan fungsi dari jantung mengalami kemunduran (vasokonstriksi pembuluh darah) yang menurunkan aliran darah ke otot jantung yang dalam jangka panjang menyebabkan nekrosis otot jantung. Seiring bertambahnya usia resiko menempelnya plak ke dinding pembuluh darah lebih besar. Faktor usia juga berkaitan erat dengan kadar kolesterol total dalam darah (hiperkolesterolemia), yang memicu obstruksi sehingga pembuluh darah menyempit, memicu peningkatan tekanan darah dan mengakibatkan penyakit jantung koroner (Kumar, 2012).

Riwayat penyakit dahulu/sebelumnya yang pernah dialami oleh responden dalam penelitian ini diantaranya Hipertensi (20.0\%) dan Diabetes Mellitus (16.7\%). Tekanan darah tinggi menyumbangkan 10.09 kali (95\% CI 8.48-12.01) beresiko mengalami penyakit jantung koroner (Ghani, Susilawati, \& Novriani, 2016). Hipertensi menyebabkan jantung memompa dan mendorong darah ke arteri dengan sangat kuat, sehingga otot jantung menjadi tebal dan besar. Dampaknya penurunan elastisitas vaskuler yang menyebabkan gangguan irama dan denyut jantung. Diabetes mellitus pada orang dewasa beresiko 2-4 kali lebih besar mengalami penyakit jantung. Diabetes mellitus mempercepat degenerasi jaringan dan disfungsi dari endotel sehingga menyebabkan menebalnya membrane basalis dari kapiler vaskuler dan arteri koronaria yang berdampak penyempitan aliran darah ke jantung (Lewis, 2011).

Hasil penelitian menunjukkan bahwa perubahan toleransi aktivitas dengan indikator keluhan saat aktivitas (frekuensi nafas), tekanan darah (sistolik), saturasi oksigen, frekuensi nadi (heart rate), menunjukkan ada perubahan $p$ value $<0.05$, kecuali pada tekanan diastolik. Hasil ini menunjukkan Ha diterima, yang artinya ada 
pengaruh intervensi rehabilitasi fisik fase I (inpatient) terhadap variabel toleransi aktivitas.

Penelitian di Amerika menunjukkan posisi terlentang terus menerus (bedrest) meningkatkan resiko penurunan sirkulasi darah dari ekstremitas bawah dan penurunan volume plasma sekitar 8\%-10\%. Bedrest dalam jangka lama meningkatkan beban jantung, peningkatan istirahat dari denyut jantung dan penurunan curah jantung (Vollman, 2010). Dampak negatif yang ditimbulkan pada serangan jantung bisa secara fisik dan psikis, diantaranya: nyeri dada, sesak nafas, kelelahan, keterbatasan melakukan aktivitas fisik dan activity daily living (Rosidawati, Ibrahim, \& Nur'aeni, 2016). Pasien PJK cenderung takut dan enggan melakukan aktivitas dikarenakan trauma dengan nyeri atau serangan jantung akan muncul kembali saat digunakan untuk bergerak. Oleh karena itu, pasien dengan penyakit jantung koroner perlu diberikan program rehabilitasi fisik yang terarah/terstruktur untuk mengembalikan kapasitas fungsi otot jantung dan arteri koroner.

Tubuh manusia didesain untuk bergerak dan melakukan aktivitas fisik, sehingga latihan fisik merupakan pola hidup manusia. Otot sebagai alat gerak aktif dan akan terjadi saat tubuh mengalami kontraksi. Fisik yang beraktivitas merupakan stressor bagi tubuh. Saat tubuh mendapatkan stressor yang teratur, rutin, dan berkesinambungan maka tubuh akan bereaksi dengan beradaptasi merubah stressor menjadi stimulator (Widiyanto, 2018). Aktivitas fisik yang terprogram akan membuat jantung mengkondisikan memompa darah dan mensuplai oksigen ke seluruh tubuh. Hal itu akan mempengaruhi kebutuhan akan oksigen, sehingga tubuh merespon meningkatkan laju kapasitas paru. Latihan fisik inpatient bertujuan meningkatkan distribusi darah, peningkatan kapasitas paru, peningkatan curah jantung, dan stroke volume serta pemendekan waktu yang dibutuhkan untuk perbaikan (recovery). Latihan fisik merangsang deep-breathing dan compliance paru sehingga banyak oksigen didistribusikan dalam darah dan karbohidrat banyak dikeluarkan sehingga vitalitas fungsi paru meningkat. Hal yang nampak, orang tidak akan cepat merasa lelah, letih, mengeluh sesak dan frekuensi nafas meningkat saat melakukan latihan/aktivitas (Widiyanto, 2018). Hasil ini sesuai dengan penelitian yang dilakukan dimana pada tabel 4.2, mean keluhan saat ADL (frekuensi nafas) sebelum latihan $23.13 \mathrm{x} /$ menit sedangkan mean frekuensi nafas setelah intervensi (hari ketiga) menjadi 18.83 x/menit.

Rehabilitasi fisik inpatient mempunyai pengaruh pada tekanan darah sistolik responden. Hasil uji Friedman pada tabel 3 menunjukkan p-value perubahan tekanan darah sistolik sebelum (pre) intervensi dan setelah hari ke-2 ( $p$-value 0.033) dan pada hari ke-3 diberikan intervensi ( $\mathrm{p}$-value 0.009). Sedangkan pada hari 1 ke 3 dan hari 2 ke 3 tidak ada pengaruh latihan fisik inpatient terhadap tekanan darah sistolik. Latihan fisik menyebabkan efisiensi fungsi jantung atau peningkatan kemampuan sesuai perubahan yang terjadi. Saat terjadi serangan iskemik, manifestasi yang terjadi adalah peningkatan tekanan darah dan selanjutnya muncul chest pain. Munculnya keluhan nyeri akan mengiringi sekresi katekolamin. Saat latihan fisik berlangsung tekanan darah akan naik banyak sesuai dengan perubahan yang terjadi, kemudian akan segera mengalami penurunan tekanan setelah 30 - 120 menit latihan selesai. Penurunan tekanan darah ini dikarenakan pembuluh darah mengalami dilatasi karena proses relaksasi setelah kontraksi karena latihan, penurunan pompa jantung.

Pasien penyakit jantung koroner (PJK) mengalami toleransi aktivitas seperti muncul keluhan sesak, peningkatan frekuensi nafas dan penurunan kadar saturasi oksigen dikarenakan adanya injury pada arteri koroner. Penurunan toleransi aktivitas akan membuat penurunan 
fungsional paru dikarenakan hipoksia. Berbaring terlalu lama di tempat tidur berdampak menurunnya oxygen uptake dan kontrol kardiovaskuler. Melalui latihan fisik toleransi aktivitas dapat diminimalkan. Peningkatan toleransi aktivitas adalah resultante dari efisiensi penggunaan oksigen di jaringan serta toleransi terhadap asam laktat (PDPI, 2013). Rehabilitasi fisik jantung fase inpatient merupakan salah satu metode untuk meningkatkan saturasi oksigen karena terjadi peningkatan kapasitas maksimal paru melalui kegiatan menghirup (inspirasi), mengeluarkan (ekspirasi), dan menggunakan oksigen. Melalui latihan fisik secara terstruktur maka kinerja sirkulasi akan membaik dengan ditandai jantung, vaskuler, dan paru menyediakan oksigen untuk kontraksi otot sehingga proses difusi dari alveoli menuju arteri menjadi lancar (Novita \& Arovah, 2010).

Latihan fisik jantung inpatient dalam penelitian ini, pada hari pertama dan kedua di awali dengan relaksasi (latihan nafas dalam) yang fungsinya meningkatkan kapasitas fungsi paru. Relaksasi nafas dalam meningkatkan fungsi otot-otot pernafasan, sehingga ventilasi menjadi maksimal dan oksigen dapat ditingkatkan. Ventilasi yang baik berdampak pada peningkatan difusi oksigen antara alveoli dengan kapiler paru yang selanjutnya meningkatkan saturasi oksigen (Rahmatina, 2012). Hal ini sesuai dengan hasil penelitian yang ada pada tabel 4.3 bahwa tingkat saturasi oksigen ( $\mathrm{SaO} 2)$ mengalami perubahan yang signifikan sejak hari pertama sampai ketiga ( $p$-value $<0.05)$.

Tabel 3 menunjukkan latihan rehabilitasi fisik fase inpatient berpengaruh terhadap frekuensi nadi (heart rate) pasien PJK setelah dua hari menjalani latihan. Sedangkan pada hari 1 ke 2 dan hari 2 ke 3 belum ada pengaruh latihan terhadap heart rate responden. Peningkatan heart rate akan meningkatkan stroke volume sehingga volume darah yang dihasilkan per menit oleh ventrikel kanan-kiri akan meningkat juga (Permata, 2018). Bersamaan dengan peningkatan tersebut, terjadi vasodilatasi vaskuler untuk mengangkut oksigen menuju ke otot jantung yang kontraksi (aktif). Rehabilitasi fisik berkaitan dengan aktivitas saraf simpatis dan parasimpatis. Program rehabilitasi inpatient menyebabkan reactivation saraf parasimpatis dan deactivation saraf simpatis sehingga menyebabkan penurunan denyut jantung secara bertahap sampai ke nilai awal (Besnier et al., 2017). Hal ini sesuai dengan hasil penelitian pada tabel 3, dimana mean heart rate saat pretest $97.33 \mathrm{x} /$ menit dan mengalami penurunan mean heart rate post-test menjadi $84.67 \mathrm{x} /$ menit.

\section{SIMPULAN}

Terdapat pengaruh program rehabilitasi fisik inpatient selama 3 hari dengan frekuensi latihan 2 kali/hari (pagi, sore) terhadap status hemodinamik (respirasi, tekanan darah sistolik dan diastolik, $\mathrm{SaO}_{2}$, heart rate) pada pasien PJK NSTEMI di Ruang ICCU RSUD Dr. Harjono Ponorogo, kecuali indikator tekanan darah diastolik tidak mengalami perubahan signifikan.

\section{UCAPAN TERIMAKASIH}

Terimakasih kepada Litmas Poltekkes Malang yang telah memberikan dana melalui program hibah penelitian BOPTN sehingga penelitian ini dapat dilaksanakan.

Penghargaan setinggi-tingginya untuk responden penelitian dan sejawat perawat di ruang ICCU RSUD Dr. Harjono Ponorogo yang berkenan berpartisipasi sebagai assisten/pembantu peneliti dalam penelitian.

\section{REFERENSI}

Asikin, M., Nuralamsyah, M., \& Susaldi. (2016). Keperawatan Medikal Bedah - Sistem Kardiovaskuler. Jakarta: Erlangga.

Bachrudin, M., \& Najib, M. (2016). Keperawatan Medikal Bedah - Sistem Kardiovaskuler. Jakarta: Pusdik SDM Kesehatan - Kemenkes RI. 
Badriyah, F. L., Kadarsih, S., \& Istanti, Y. P. (2010). Rehabilitasi Jantung Post Sindrome Koroner Akut Untuk Memperbaiki Hemodinamik dan EKG di Wilayah Taman Sidoarjo. 34-46.

Besnier, F., Labrunée, M., Pathak, A., Pavy-Le Traon, A., Galès, C., Sénard, J. M., \& Guiraud, T. (2017). Exercise training-induced modification in autonomic nervous system: An update for cardiac patients. Annals of Physical and Rehabilitation Medicine, 60(1), 27-35. https://doi.org/10.1016/j.rehab.2016.07.002

Biro Komunikasi dan Pelayanan Masyarakat. (2017). Penyakit Jantung Penyebab Kematian Tertinggi, Kemenkes Ingatkan Cerdik.

Delima, P. P., Sriati, A., \& Nur'aeni, A. (2018). Illness Cognition pada Pasien dengan Penyakit Jantung Koroner. Journal of Nursing Care, 1(1), 42. https://doi.org/10.24198/jnc.v1i1.15763

Ghani, L., Susilawati, M. D., \& Novriani, H. (2016). Faktor Risiko Dominan Penyakit Jantung Koroner di Indonesia. Buletin Penelitian Kesehatan, 44(3), 153-164. https://doi.org/10.22435/bpk.v44i3.5436.15 3-164

Hernawati. (2006). Produksi Asam Laktat Pada Exercise. FPMIPA Universitas Pendidikan Indonesia, 2(2), 153. https://doi.org/10.1016/j.jns.2003.09.014

Kemenkes, B. L. (2014). Situasi Kesehatan Jantung. Jakarta.

Kumar, P. (2012). Coronary Artery Disease Clinical Medicine Eigh Edition. Spain: International Edition.

Lavie, C. J., \& Milani, R. V. (2011). Cardiac rehabilitation and exercise training in secondary coronary heart disease prevention. Prog Cardiovasc Dis, May-Jun(53(6)), 397-403.

Lewis, E. A. (2011). Medical Surgical Nursing: Assesment and Management of Clinical Problems, Seven Edition Vo. 2. Mosby: Elsevier.

Lilly, L. S. (2011). Pathophysiology of Heart Disease: A Collaborative Project of Medical Students and Faculty, 5th edition. Philadelphia: Lippincott William \& Wilkins.

Mozaffarian, D., Benjamin, E. J., Go, A. S., Arnett, D. K., Blaha, M. J., Cushman, M., ... Turner, M. B. (2016). Heart Disease and Stroke Statistics2016 Update. Circulation, 133(4). https://doi.org/10.1161/CIR.0000000000000 350
Muttaqin, A. (2012). Asuhan Keperawatan Klien dengan Gangguan Sistem Kardiovaskuler dan Hematologi. Jakarta: Salemba Medika.

Neumar, Otto, Link, Kronick, Callaway, Shuster, \& Et, A. (2010). Part 8: Adult Advanced Cardiovascular Life Support: 2010 American Heart Association Guidelines for Cardiopulmonary Resucitation and Emergency Cardiovascular Care Circulaation. 122. https://doi.org/10.1161/CIRCULATIONAHA.1 10.970988

Novita, O., \& Arovah, I. (2010). Program Latihan Fisik Rehabilitatif. Medikora, VI, No.1, 11-22.

Overbaugh, K. J. (2009). Acute Coronary Syndrome. American Journal of Nursing (AJN), 109(5), 4252.

PDPI. (2013). Pedoman Diagnosis dan Penatalaksanaan Penyakit Paru Obstruktif Kronis (PPOK) di Indonesia.

PERKI. (2015). Pedoman Tatalaksana Gagal Jantung. Jakarta: Indonesian Heart Association.

Permata, A. (2018). Pelatihan Interval Intensitas Tinggi Lebih Meningkatkan Kebugaran Fisik daripada Senam Aerobik High Impact pada Mahasiswa Program Studi D-III Fisioterapi Universitas Abdurrab. Jurnal Ilmiah Fisioterapi (JIF), 1, No. 1(9), 1689-1699. https://doi.org/10.1017/CB0978110741532 4.004

Rahmatina. (2012). Buku Ajar Fisiologi Jantung. Jakarta: EGC.

Riskesdas. (2018). Hasil Utama Riskesdas Penyakit Tidak Menular 2018. In Hasil Utama Riskesdas Penyakit Tidak Menular.

Rokhaeni, H., Purnamasari, E., \& Rahayoe, A. U. (2001). Buku Ajar Keperawatan Kardiovaskuler. Jakarta: Bidang Diklat PK Jantung dan Pembuluh Darah Harapan Kita.

RSUD. Harjono Ponorogo, R. M. (2017). Sensus Bulanan. Ponorogo.

Ryandini, F. R., Nurachmah, E., Herawati, T., Adam, M., \& Sekarsari, R. (2017). Penerapan Teori Self Care Untuk Mengatasi Intoleransi Aktivitas Pada Pasien Dengan Gangguan Sistim Kardiovaskular. Jurnal Keperawatan Indonesia, 1-8.

Sudibjo, P., Arovah, N. I., \& A, R. L. (2013). Tingkat Pemahaman Dan Survei Level Aktivitas Fisik, Status Kecukupan Energi Dan Status 
Antropometrik Mahasiswa Program Studi Pendidikan Kepelatihan Olahraga FIK UNY. Medikora, 11(2), 183-203.

Suharsono, T. (2013). Dampak Home Based Exercise Training Terhadap Kapasitas Fungsional Pasien Gagal Jantung. Ejournal.Umm.Ac.Id, 4(1), 63-68.

Vollman, K. M. (2010). Introduction to Progressive Mobility. Critical Care Nurse, 30(2), S3-S5. https://doi.org/10.4037/ccn2010803

Widiyanto. (2018). Respon Kardiovaskuler Akibat Latihan. Medikora, IV, No. 1, 24-46.

Zanto, T. P., Hennigan, K., Östberg, M., Clapp, W. C., \& Gazzaley, A. (2011). Medication Adherence, Depressive Symptoms, and Cardiac Event-Free Survival in Patients with Hearth Failure. 46(4), 564-574.

https://doi.org/10.1016/j.cortex.2009.08.003

Predictive 